\title{
燃料电池商用车产业发展现状与展望
}

\author{
谭旭光 $^{1}$, 余卓平 $^{2}$ \\ (1. 潍柴动力股份有限公司, 山东漼坊 261061；2. 同济大学汽车学院, 上海 201804）
}

摘要: 面对全球严峻的节能减排与能源紧缺形势, 国内外都将燃料电池汽车作为汽车行业的未来战略方向, 高能耗高排放的 商用车技术变革更显迫切。本文分析了国内外燃料电池汽车产业的发展动态, 梳理了主要国家在燃料电池汽车开发和推广过 程中所采取的各项举措, 总结了我国燃料电池汽车产业发展的优势与面临的问题。研究表明, 基于国家级产业引导政策, 燃 料电池汽车发展路线应以商用车为主; 针对制约燃料电池商用车发展的因素, 建议通过顶层设计, 出台产业专项规划以明确 产业发展的方向、目标和重点; 强化燃料电池关键共性技术研发突破, 解决制约产业快速发展的瓶颈问题, 推动燃料电池汽 车产业高质量发展。

关键词: 燃料电池; 商用车; 氢能; 新能源

中图分类号: TM911.48 文献标识码: A

\section{Development Status and Prospects of Fuel Cell Commercial Vehicle Industry}

\author{
Tan Xuguang ${ }^{1}$, Yu Zhuoping ${ }^{2}$ \\ (1. Weichai Power Co., Ltd., Weifang 261061, Shandong, China; 2. School of Automotive Studies, \\ Tongji University, Shanghai 201804, China)
}

\begin{abstract}
In view of the severe energy conservation and emission reduction, fuel cell vehicles are regarded globally as an important strategic direction of the automotive industry, and technological changes for commercial vehicles with high energy consumption and high emission become urgent. In this article, we analyzes the development trends of the fuel cell vehicle industry in China and abroad, introduces the various measures taken by major countries in the development and promotion of fuel cell vehicles, and summarizes the advantages and challenges faced by China in the development of fuel cell vehicles. This study reveals that the development route of fuel cell vehicles should focus on commercial vehicles based on China's guiding policies for the fuel cell vehicle industry. Considering the factors restricting the development of fuel cell commercial vehicles, it is recommended to clarify the direction, goals, and priorities of the industry by adopting top-level design and introducing special industrial plans; research and development should be strengthened in key generic technologies of fuel cells to solve major obstacles that restrict the development of the industry, thereby promoting the high-quality development of the fuel cell vehicle industry.
\end{abstract}

Keywords: fuel cell; commercial vehicle; hydrogen energy; new energy

收稿日期 : 2020-06-06; 修回日期 : 2020-07-24

通讯作者: 谭旭光, 潍柴动力股份有限公司正高级工程师, 主要研究方向为商用车动力总成; E-mail: $\operatorname{tanxg@weichai.com~}$ 资助项目：国家重点研发计划项目 (2018YFB0106500)

本刊网址： www.engineering.org.cn/ch/journal/sscae 


\section{一、前言}

能源是国民经济社会发展的基础和命脉, 能源 安全直接关乎国家和社会安全。当前我国对海外原 油资源依赖程度较高, 能源安全存在隐患 [1], 同 时化石能源使用产生的碳排放也构成了一定的环 保压力。随着国家能源战略结构调整、生态文明 建设向纵深推进, 传统能源转型升级已成为时代 趋势, 能源消费的低碳化、清洁化已成为主流。 新型能源的产业化应用, 有助于推动能源生产与 消费革命、优化能源结构、助力能源安全、实现 温室气体减排和生态环境保护、提升国家工业装 备制造水平 [2]。

氢能是零排放、可再生能源, 推广氢能应用成 为解决能源危机和环境污染危机的良好路径。在全 球氢能源加速发展的背景下, 燃料电池汽车成为各 国机构和企业研发的重点内容之一。2019 年, 美 国能源部发布了燃料电池 8 级卡车发展目标, 提出 到 2030 年燃料电池系统寿命达到 $25000 \mathrm{~h}$ 、峰值 效率超过 $68 \%$ 。日本和韩国多家汽车公司应用金 属双极板电堆技术, 推出了适用于乘用车的燃料电 池动力系统解决方案。在商用车方面, 基于石墨极 板电堆的燃料电池成为极富潜力的动力系统解决方 案, 欧洲多家汽车公司联合发展了重型车辆用燃料, 电池系统, 德国博世公司开发的燃料电池系统拟于 2020 年年底推向市场。

与国际进展同步，我国也在持续加大氢能源 在交通领域的研发和投入力度, 积极推动燃料电 池汽车的投产应用 [3]。中国科学院大连化学物理 研究所 [4] 梳理了材料、关键组件、电堆、系统 等燃料电池汽车的技术现状，分析提出了燃料电 池性能衰减规律与提升策略。我国在 “十五” 至 “十三五” 时期持续布局新能源相关重大专项, 通 过 “产学研” 联合研发模式, 攻关突破了一批燃 料电池汽车关键技术, 较好掌握了燃料电池关键 材料与组件、电堆集成、系统和整车匹配以及加 氢基础设施建设等核心技术 [5]。清华大学技术团 队 [6] 研究了国内外燃料电池汽车核心技术开发、 推广应用所面临的共性问题, 阐述了我国燃料电 池汽车产业的发展态势, 探讨适合国情的燃料电 池发展路径。

本文着眼于能源转型的重大战略价值, 就国
际氢能及燃料电池汽车的发展格局与发展态势开 展梳理; 论证我国燃料电池商用车的发展路线, 研判制约产业发展的关键因素; 立足国家产业发 展引导政策，提出具体的技术创新发展方向以及 发展建议, 以期为燃料电池商用车产业研究提供 理论参考。

\section{二、发展燃料电池商用车产业的战略意义}

燃料电池汽车的广泛应用是支撑实现节能减排 和可持续发展的重要技术方向。美国、欧盟、日本、 韩国等国家或地区在燃料电池汽车领域开展了较多 的技术研究和应用推广工作, 体现了高端制造业快 速发展的势头。与之对应, 发展燃料电池汽车对我 国汽车制造业的科技进步与高质量发展构成正向推 动力, 促进产业由传统制造向高端制造转变。

在汽车发展方面, 截至 2019 年年底, 我国 民用汽车保有量为 $2.615 \times 10^{8}$ 辆, 其中商用车为 $4.05 \times 10^{7}$ 辆, 占比为 $15.5 \%[7]$ 。较高的商用车保有 量带来了高污染与高能源消耗问题, 如石油消费总 量约有 $50 \%$ 来自于交通运输业 [8]。商用车从传统 动力向无污染的氢燃料动力转型, 这是实施节能减 排行动的主要方向之一。

在能源利用方面, 尽管商用车的售出量远低于 乘用车, 但是商用车整体燃油消耗远超乘用车 [9], 因此在商用车领域推广新能源技术的原油替代效果 会更为显著。目前, 城市公共交通领域的电动化趋 势日益明显; 对于工作时间长、运行里程长, 特别 是在特定区域范围内运行的商用车, 高储能密度的 氢燃料电池动力源将是更有价值的选择。

在国家政策方面, 2019 年政府工作报告提出了 “推动加氢设施建设” 的任务部署, 标志着燃料电 池汽车发展驶入 “快速通道”。《新能源汽车产业 发展规划（2021-2035 年)》也增加了合理布局加 氢基础设施, 推进氢燃料供给保障体系的相关内 容。根据产业规划, 到 2030 年氢能将成为新能源 战略布局的重要组成部分, 氢能产业也将支撑经 济增长。

相比电动汽车、混合动力汽车, 燃料电池汽车 在补加燃料时间和续驶里程方面具有优势。对于续 驶里程较长、动力性能要求较高、汽车体积较大的 商用车，燃料电池是公认的优选技术方案; 商用车 
运行在相对固定的线路上, 对加氢站的依赖性低于 乘用车。因此在燃料电池产业发展的初期, 发展燃 料电池商用车的价值高于乘用车。

\section{三、氢能及燃料电池汽车产业发展现状}

\section{（一）国外发展情况}

在能源安全、碳排放限值等日益突出的能源环 境问题背景下, 诸多国家或地区均设置专门管理机 构、投入大量资源、推出相关规划与政策, 促进氢 能及燃料电池产业的快速发展。

\section{1. 技术发展}

美国、欧盟、日本、韩国的燃料电池研发起 步较早, 在乘用车用燃料电池技术方面已经形成 技术领先优势。美国早在 1970 年提出了氢经济概 念, 将氢能及燃料电池列入能源战略, 近 10 年的 经费支持规模超过 16 亿美元。日本汽车公司的燃 料电池汽车性能先进, 其燃料电池商业化应用处于 世界领先位置; 氢动力卡车也成为了汽车企业合 作开发的重要方面。德国在 2006 年启动了氢能和 燃料电池技术国家发展计划 (NIP), 以国家中心 (NOW-GmbH) 的组织形式推进技术开发工作; 计 划 2025 年燃料电池乘用车成本与当前的电动车相 当。韩国在 2003 年将氢能定位为 “ 21 世纪前沿科 学计划” 的主要技术领域之一, 相关汽车公司与瑞 典企业共同研发燃料电池核心技术。

\section{2. 政策支持}

美国发布了以《国家氢能路线图》为代表的 多个氢能规划, 通过《氢燃料电池开发计划》《能 源政策法》等政策支持氢能技术研发和示范应用, 将 10 月 8 日定为美国国家氢能与燃料电池纪念 日。日本在 2013 年将发展氢能列入国家计划, 提 出了建设氢能社会的远期目标; 《氢能利用进度表》 （2019年）明确了 2030 年氢能应用的具体目标。欧 盟从能源战略层面先后发布了《 2030 气候和能源框 架》《2050 低碳经济战略》等政策, 成立了燃料电 池联盟来共同推进关键技术和产业发展。2020 年, 韩国发布了《促进氢经济和氢安全管理法》以促进 基于安全的氢经济建设, 明确了政府对氢能产业和 氢能企业的行政和财政支持, 涵盖氢能企业培育、 援助、人才培养、产品标准化等产业基础事项; 弥 补了《高压气体法》《燃气法》的不足, 为电解水
制氢等低压氢气设备和氢燃料使用设施的安全管理 提供了法律依据。

\section{3. 市场运营}

美国的燃料电池汽车推广与运营量较大, 美国 燃料电池与氢能协会 (FCHEA) 在其发布的 “氢 能经济路线图” 中提出, 2030 年美国燃料电池汽车 数量预计达到 $5.3 \times 10^{6}$ 辆 $[10]$ 。韩国推广燃料电池 车辆超过 5000 辆, 建成加氢站 34 座, “氢能经济 发展路线图” 规划 2040 年燃料电池汽车累计产量 为 $6.2 \times 10^{6}$ 辆 [11]。2019 年日本燃料电池车辆保有 量达到 3500 辆, 加氢站超过 120 座; 按照 “氢能 利用进度表” 规划, 2030 年燃料电池乘用车保有量 为 $8 \times 10^{5}$ 辆, 燃料电池公交车数量为 1200 辆, 加 氢站数量为 900 座 [12]。欧盟在燃料电池推广方面 积极较高, 示范推广燃料电池乘用车达到 1080 辆、 燃料电池商用车 150 余辆, 20 个国家共建成 177 座 加氢站。“欧洲氢能路线图” 提出, 2030 年将推 广应用 $3.7 \times 10^{6}$ 辆乘用车、 $5.0 \times 10^{5}$ 辆轻型商用车、 $4.5 \times 10^{4}$ 辆重型载货车和公交车、570 辆列车 [13]。

\section{4. 地区发展}

美国加利福尼亚州是全球燃料电池乘用车主 要集中地, 也是全球燃料电池车推广最为成熟的地 区。韩国因地制宜, 按区域逐步开放氢能经济发展, 将安山、蔚山、万州和全州确定为 “氢能经济候选 城市”。法国波城启用了全球首款燃料电池快速公 交 (BRT), 车辆长 $18 \mathrm{~m}$, 续航里程超过 $300 \mathrm{~km}$, 百千米氢耗为 10 12 kg, 性能堪比有轨电车, 但综 合投资降低至 $1 / 4$ 。

\section{（二）国内发展情况}

近年来, 我国从发展路线、产业规划、补员措 施（阶段性）等方面出台了系列政策，全方位支持 燃料电池产业发展。以 “节能与新能源汽车技术路 线图” [5] 为代表的发展规划, 均将氢能及燃料电池 列为支持发展产业。

\section{1. 产业宏观态势}

2016-2019 年, 国内燃料电池汽车销量大幅增 加 (见图 1)。根据中国汽车工业协会《2019 年汽车 工业经济运行情况》数据统计, 2019 年我国燃料电 池汽车产销量分别为 2833 辆、2737 辆, 同比增长 $85.5 \% 、 79.2 \%$ 。2 2020 年上半年因新型冠状病毒肺 炎疫情原因导致产销量有所下降。截至2020年6月, 
我国燃料电池汽车累计销售超过 6000 辆。从汽车 销量数据来看, 我国燃料电池汽车产业发展方向与 国外存在明显不同：美国、日本、韩国和欧盟的燃 料电池汽车推广以乘用车为主, 而我国以商用车为 主, 已实现量产并投入规模化运营。

按照 “节能与新能源汽车技术路线图” 预测: 2025 年, 随着燃料电池关键技术成熟度的提高, 燃 料电池汽车推广量可达到 $1 \times 10^{5}$ 辆; 2030 年, 随 着燃料电池核心组件技术持续突破, 燃料电池汽 车规模化应用达到 $1 \times 10^{6}$ 辆。《中国氢能源及燃料 电池产业白皮书》预测 [14]: 在商用车应用方面, 2030 年燃料电池商用车推广应用量将为 $3.6 \times 10^{5}$ 辆, 占商用车总销量的 $7 \% ; 2050$ 年将为 $1.6 \times 10^{6}$ 辆, 市 场占比达到 37\%；2050 年交通领域的氢能消费量将 为 $2.458 \times 10^{7} \mathrm{t} / \mathrm{a}$, 占交通领域整体用能的 $19 \%$, 其 中货运领域的商用车氢能消费占交通领域氢能消费 的比重达到 $70 \%$, 成为交通领域氢能消费增长的主 要驱动力。

\section{2. 区域发展情况}

我国在燃料电池汽车方面保持了较强的产业扶 持力度。截至 2019 年年底, 已有 19 个省市、 40 余个 地级市出台了推动氢能及燃料电池产业发展的政策 规划, 鼓励燃料电池公交车、物流车等商用车的 示范运营, 初步形成了京津冀、华东、华南、西 南、华中五大燃料电池汽车应用集群。例如, 山东 省作为华东然料电池汽车产业集群的重要省份, 产 业覆盖氢气制备、储运、加注、燃料电池发动机及 关键零部件、燃料电池汽车等领域, 多家行业龙

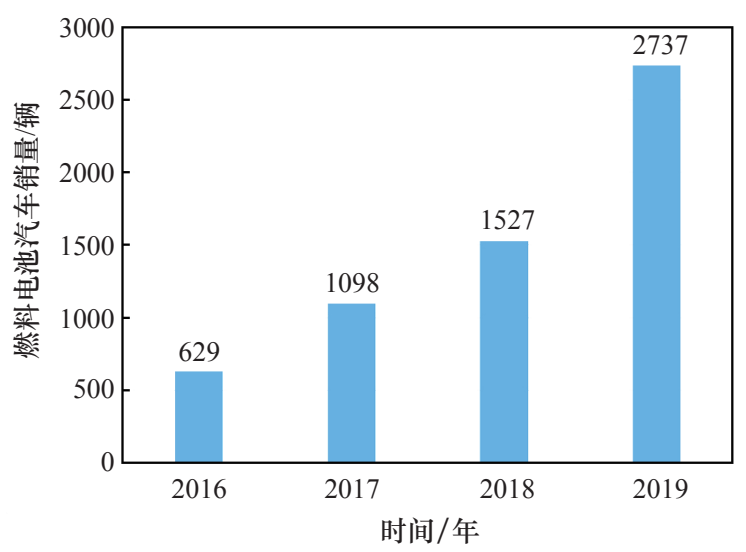

图 1 我国历年燃料电池汽车销量情况

注: 数据来自中国汽车工业协会发布的《2016 年汽车工业经济运行情况》 《2017 年汽车工业经济运行情况》 《2018 年汽车工业经济运行情况》 《2019 年汽车工业经济运行情况》。
头企业均取得了相应的技术攻关和产业应用突破。 截至 2020 年 6 月, 山东省示范推广燃料电池商用 车超过 200 辆, 运行公交线路 7 条, 总里程超过 $1.6 \times 10^{6} \mathrm{~km}$ ，建成加氢站 6 座。

在国家政策引导下, 多个地区重视氢能及燃料 电池产业的落地发展, 出现了佛山、张家口、郑 州、成都等燃料电池车辆推广积极、区位优势较 为明显、产业链相对完善、产业集群化程度领先 的氢能城市。此外, 《天津市氢能产业发展行动方 案（2020-2022 年)》规划, 2022 年力争建成至少 10 座加氢站, 打造 3 个燃料电池车辆推广应用试点 示范区; 《常熟氢燃料电池汽车产业发展行动计划 (2019-2022 年)》提出, 2022 年燃料电池汽车累 计推广达到 3000 辆, 建成 2 3 座市场化运营的公 共加氢站, 培育燃料电池汽车企业 1 2 家; 《潍坊 市氢能产业发展三年行动计划（2019-2021 年)》 要求, 在产业链层面聚焦包含核心材料、关键组 件、电堆开发、系统集成、测试认证、整车匹配 等环节在内的产业集群, 培育与产业发展要求配 套的新能源创新中心和测试中心。

\section{四、燃料电池商用车产业面临的问题及对策 建议}

我国燃料电池商用车示范已经走在了世界前 列，这是企业技术创新与国家政策支持协同发力的 成果。也要注意到, 不少关键技术方向仍未完全突 破, 商用车燃料电池的发展还面临着一些基础性的 制约因素。

\section{（一）氢能和燃料电池产业发展的国家标准与法规 体系有待完善}

我国氢能和燃料电池产业的发展速度很快, 但氢能燃料电池全产业链的技术和检测规范以及 相关法规尚有欠缺, 体系完整性有待加强。现行 的法规标准仍将氢气按照危险化学品进行管理, 导致加氢站审批、建设和运营的扩大化受到制约。 针对上述问题, 建议细化氢能和燃料电池关键材 料与核心部件的开发规范, 建设氢能燃料电池国 家技术标准创新基地, 完善产业技术发展重点方 向和目标, 优化区域产业布局。在明确车用氢气 的能源属性之后, 细化车用氢气的制备、储运、 
加注技术标准, 为加速氢能基础设施建设提供 保障。

\section{（二）关键材料和核心技术尚未完全自主}

燃料电池技术研发取得了长足进展, 但在核心 材料、关键组件的自主研发方面仍存在较大差距。 催化剂、质子膜、碳纸、空压机等对国外依赖度较 大, 氢气品质、储存运输、加氢站建设等方面的质 量和安全标准不足, 氢品质和氢泄露等高精度检测 设备以及权威检测机构欠缺, 严重制约了燃料电池 产业的发展。针对氢能产业技术不成熟、产业发展 不经济等情况, 应统筹规划, 发挥政策对产业薄弱 环节的支持和引导作用; 合理加强对企业氢能研 究的支持, 激发企业技术创新的主体作用; 强化 “产学研” 协同攻关, 发挥联合优势以促进核心技 术突破。

\section{（三）加氢基础设施布局尚不完善}

“加氢焦虑” 成为制约燃料电池汽车发展的重 要因素之一。在燃料电池汽车推广的初期, 鉴于运 营车辆较少, 市场化的公共加氢站难以通过规模经 济效应实现收支平衡, 因营利困难致使相关设施建 设的积极性不高, 2015-2019 年全球投入运营的加 氢站数量增长缓慢 (见图 2)。基础设施不足直接 制约了燃料电池汽车推广应用的规模。鉴于此, 可 在政策层面优化加氢站建设审批程序和运营监管规 定, 同时进一步提高加氢基础设施材料、核心组件 和技术 (如新型储氢材料、液氢(储运) 的国产化比例, 通过技术进步来降低加氢站建设成本。相比乘用车,

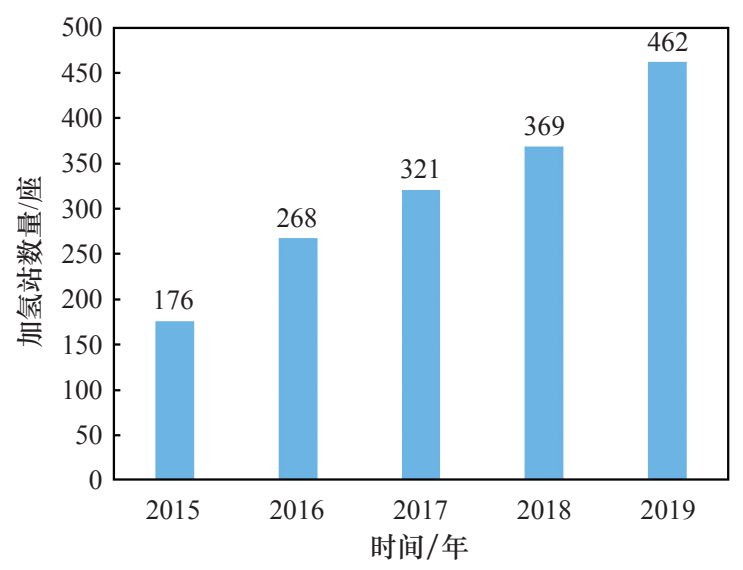

图 2 2015-2019 年全球加氢站数量 [15]
商用车的运营路线比较固定，在商用车的典型运营 路线上建设加氢站, 可大幅降低对基础设施的依赖 程度, 进而在加氢站密度偏低的情况支持燃料电池 车辆的常态化运营。

\section{（四）燃料电池车辆购置和使用成本仍然较高}

燃料电池成本偏高依然是燃料电池车辆推广 应用的主要制约因素。美国能源部从整车、燃料 电池系统、电堆成本等方面对燃料电池车的构成 成本进行了分析 (见图 3), 相比之下我国燃料 电池系统的实际成本与美国还存在差距。虽然我 国多个地区结合自身产业实际开展了燃料电池车 辆的示范应用, 但车辆运营成本与传统燃油车辆 相比不具优势; 加氢站建设成本高、运营收支难 以平衡等问题比较明显, 全产业链的利润分配没 有得到有效平衡, 各个环节的价值没有得到合理 体现。

目前我国的燃料电池商用车已进入产业化发展 的初期阶段, 为加强竞争力以更好参与全球燃料电 池产业和技术市场, 应提高燃料电池关键材料与核 心组件、加氢站核心部件和关键技术的国产化率, 推动燃料电池汽车制造和加氢站建设成本的大幅降 低。在氢资源丰富的地区率先开展燃料电池汽车的 商业化推广, 有效降低氢气使用成本; 随后通过技 术提升和市场辐射, 带动我国氢能燃料电池产业的 整体技术进步和产业发展。

\section{五、燃料电池商用车产业发展展望}

燃料电池商用车因其在燃料加注时间、续驶里 程和耐久性等方面的特性, 将与纯电动汽车形成长 期的互补优势, 助力我国从汽车制造业大国走向强 国。在一定的发展周期内, 氢能及燃料电池汽车产 业链日益完善, 氢能基础设施的完善度与便利程度 逐步提升, 氢气价格和燃料电池系统成本将持续下 降, 这些是燃料电池商用车市场竞争力的重要支撑 因素。具体而言, 我国燃料电池商用车产业的发展 将呈现以下趋势。

(1) 得益于国家相关政策支持和 2022 年北京 冬季奥运会等重大活动的需求牵引, 燃料电池商用 车产业将继续处于快速发展态势。发展燃料电池商 用车, 必将打通燃料电池汽车产业链、完善氢能基 


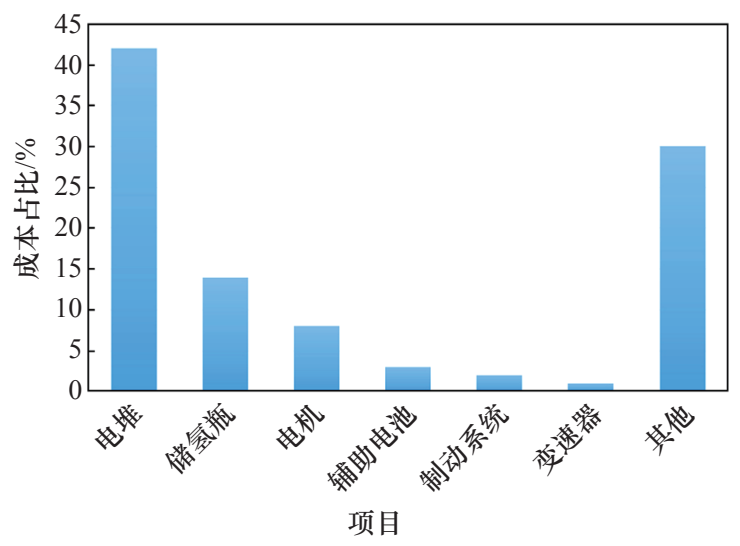

（a）整车成本构成

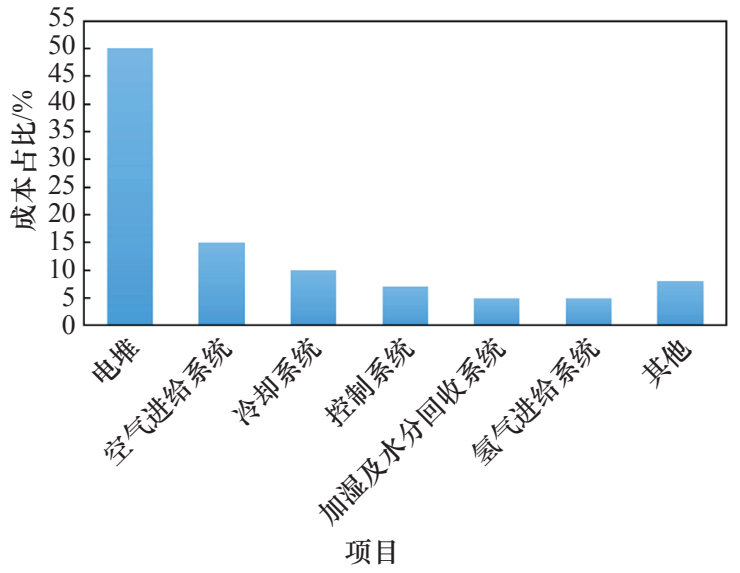

（b）燃料电池系统成本构成

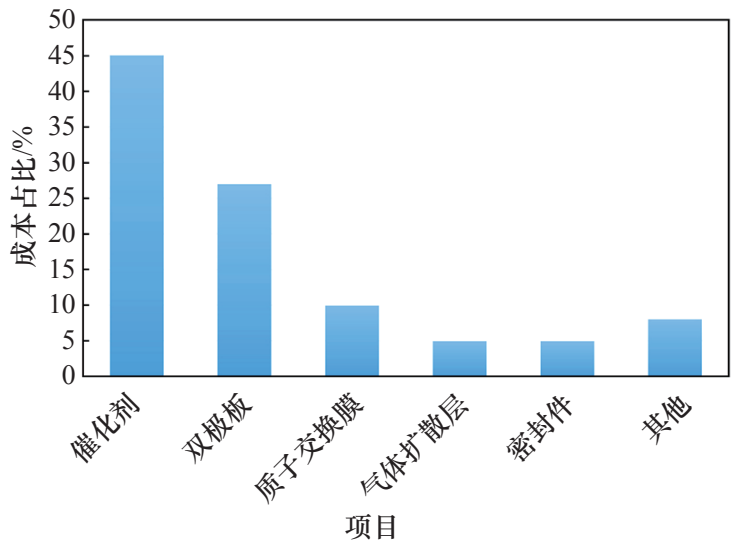

（c）电堆成本构成

图 3 燃料电池汽车成本构成 [16]

础设施建设、建立健全行业标准法规、降低部件及 整车成本。通过技术进步和规模化效应, 积极面对 国家补贴随着产业发展而不断退坡的局面，打牢基 础以更好适应后续进入的优胜劣汰与充分竞争阶 段，促进产业化向纵深发展。

（2）燃料电池商用车在城市公交、物资流通等
领域率先应用之后，伴随着氢能及燃料电池的技术 发展与成本下降, 将朝着港口码头、特定路线的轨 道交通、城际物流、城际客运等领域拓展。考虑到 不同地区的能源结构差异性，燃料电池商用车和纯 电动商用车将进入长期共存、互为补充的市场应用 状态。

（3）第五代移动通信技术深化应用、车辆智能 驾驶技术趋于成熟, 赋予了燃料电池商用车与汽车 高智能化融合发展的宝贵机遇，“燃料电池技术 + 智能驾驶技术” 将成为产业应用创新的重点方向。 燃料电池技术将促进商用车成本降低, 高智能化带 来的舒适驾驶体验将推动商业运输业的快速发展, 从而为经济社会活动提供更加便捷和环保的交通出 行服务。

\section{参考文献}

[1] 中国石油集团经济技术研究院. 2019年国内外油气行业发展报 告 [R]. 北京: 中国石油集团经济技术研究院, 2020 .

CNPC Economics \& Technology Research Institute. 2019 domestic and foreign oil and gas industry development report [R]. Beijing: CNPC Economics \& Technology Research Institute, 2020.

[2] 黄其励, 彭苏萍. 能源领域培育与发展研究报告 [M]. 北京: 中 国科技出版传媒股份有限公司, 2015.

Huang Q L, Peng S P. Research reports on fostering and developing strategic emerging industries in energy field [M]. Beijing: China Science Publishing \& Media Ltd., 2015.

[3] Frano B. PEM fuel cells: Theory and practice (2nd edition) [M]. Washington, DC: Academic Press, 2013.

[4] 衣宝廉. 燃料电池和燃料电池车发展历程及技术现状 [M]. 北 京: 中国科技出版传媒股份有限公司, 2018.

Yi B L. Development history and technical status of fuel cells and fuel cell vehicles [M]. Beijing: China Science Publishing \& Media Ltd., 2018.

[5] 节能与新能源汽车技术路线图战略咨询委员会, 中国汽车工程 学会. 节能与新能源汽车技术路线图 [M]. 北京:机械工业出版 社, 2016 .

Strategic Advisory Committee on Energy Saving and New Energy Vehicle Technology Roadmap, China Society of Automotive Engineers. Technology roadmap for energy saving and new energy vehicles [M]. Beijing: China Machine Press, 2016.

[6] 刘宗巍, 史天泽, 郝瀚, 等. 中国燃料电池汽车发展问题研究 [J]. 汽车技术, 2018 (1): 1-9.

Liu Z W, Shi T Z, Hao H, et al. Research on main problems associated with development of fuel cell vehicle in China [J]. Automobile Technology, 2018 (1): 1-9.

[7] 中华人民共和国交通运输部. 2019年交通运输行业发展统计 公报 [EB/OL]. (2020-05-12) [2020-06-04]. http://xxgk.mot.gov. cn/2020/jigou/zhghs/202006/t20200630_3321335.html.

Ministry of Transport of the People's Republic of China. Statistical 
bulletin of transportation industry development in 2019 [EB/OL]. (2020-05-12) [2020-06-04]. http://xxgk.mot.gov.cn/2020/jigou/ zhghs/202006/t20200630_3321335.html.

[8] 电力规划设计总院. 中国能源发展报告2018 [R]. 北京: 电力规 划设计总院, 2019.

China Electric Power Planning \& Engineering Institute. China energy development report 2018 [R]. Beijing: China Electric Power Planning \& Engineering Institute, 2019.

[9] 能源与交通创新中心. 2014-2018中国商用车油耗发展研究报 告 [R]. 北京: 能源与交通创新中心, 2020 .

Innovation Center for Energy and transportation. 2014-2018 China commercial vehicle fuel consumption development research report [R]. Beijing: Innovation Center for Energy and Transportation, 2020.

[10] Fuel Cell and Hydrogen Energy Association. Road map to a US hydrogen economy [R]. Washington, DC: Fuel Cell and Hydrogen Energy Association, 2019.

[11] Yonhap News Agency. S. Korea begins crafting road map for hydrogen economy [EB/OL]. (2019-02-26) [2020-06-04]. https:// en.yna.co.kr/view/AEN20190226003800320.

[12] Ministry of Economy, Trade and Industry, Japan. METI has compiled a strategic read map for hydrogen and fuel cells [EB/ OL]. (2014-06-24) [2020-06-04]. https://www.meti.go.jp/english/ press/2014/0624_04.html.

[13] Fuel Cells and Hydrogen, Joint Undertaking. Hydrogen roadmap Europe: A sustainable pathway for the European energy transition [EB/OL]. (2019-02-26) [2020-06-04]. https://www.fch.europa.eu/ sites/default/files/Hydrogen\%20Roadmap\%20Europe_Report.pdf.

[14] 中国氢能联盟. 中国氢能源及燃料电池产业白皮书 [R]. 北京: 中国氢能联盟, 2019 .

China Hydrogen Alliance. White paper on China's hydrogen energy and fuel cell industry [R]. Beijing: China Hydrogen Alliance, 2019.

[15] 中商产业研究院. 2019年中国加氢站市场发展前景及投资研究 报告 [R]. 深圳: 中商产业研究院, 2019.

China Merchants Industry Research Institute. 2019 China hydrogen station market development prospects and investment research report [R]. Shenzhen: China Merchants Industry Research Institute, 2019.

[16] Department of Energy. DOE hydrogen and fuel cells program record: Fuel cell system cost-2015 [EB/OL]. (2015-10-22) [2020-06-04]. https://www.hydrogen.energy.gov/pdfs/15015_fuel_ cell_system_cost_2015.pdf. 